\title{
Developments of red steppe breed heifers and its hybrids with Holstein in the period of pregnancy and after calving
}

\author{
Patimat Aligazieva ${ }^{1, *}$, Gyulkhanum Dabuzova ${ }^{1}$, Habib Kebedov ${ }^{1,}$ Abdula Aligaziev $^{1}$, and \\ Ibragim Abdulaev ${ }^{1}$ \\ ${ }^{1}$ Dagestan State Agrarian University, Makhachkala, Russia
}

\begin{abstract}
Holstein stud-bulls, selected as improvers, directly have a significant impact on the growth rate of live weight of the resulting offspring. The live weight of crossbred heifers at 18 months of age was $377-388 \mathrm{~kg}$, which is $8-10 \%$ higher than that of pure-bred red-steppe peers. At the same time, animals with a blood share of $50 \%$, bred "in themselves" are characterized by the best indicators of absolute and relative increase in live weight and have a more pronounced milky type of physique on the exterior. Currently, the main place in the structure of the herd of cattle is occupied by the breeding stock, the number of which is increasing every year. The proportion of cows in the herd is increasing over the years is $46.5 \%$, and the rest of the livestock is also increasing accordingly. When growing heifers of cattle, $55-60 \%$ of all costs in the structure of their cost are feed stuff. Consequently, the efficiency of rearing is mainly caused by feed conversion ratio increase in muscle, fat and bone tissue, which provides a high level of efficiency of young animals. In our experience, when growing heifers of different genotypes, feeding was carried out according to the norms of the All-Russian research Institute of animal husbandry. The diet structure contained the required amount of concentrates, hay, silage and green fodder.
\end{abstract}

\section{Introduction}

The main planned breed, bred in the conditions of the flat zone of Dagestan, including in OJSC "Kizlyaragrokompleks" of the Kizlyar region, is the red steppe. A feature of the red steppe cattle is its exceptional unpretentiousness and the ability to easily adapt to various natural and climatic conditions. Due to these properties, the red steppe breed is zoned in the North Caucasus. Due to the fact that animals of this breed are characterized by certain disadvantages: a relatively low level of milk productivity, uneven milk yield in the herd, poor adaptability to the conditions of industrial technology, Holstein began to be imported to eliminate the above disadvantages. Therefore, in the agricultural complex, in order to improve these qualities, as in some farms of the republic, they began to cross between red steppe cows with Holstein bulls. Holstein cattle adapt very well to industrial technology

${ }^{*}$ Corresponding author: p.aligazieva@mali.ru 
and are distinguished by good health. Poorly expressed meat productivity affects high milk productivity with the best indicators of milk constituents. Holstein cows have well-defined milky forms, with not very developed muscles, the udder has an index of 48-50\%, a bowlshaped, voluminous, wide belly, firmly attached to the wall, and a milk flow rate of at least $2.5 \mathrm{~kg} / \mathrm{min}$. At present, hybrids of different bloods from Holstein have been obtained. To increase the level of milk productivity and provide the country's population with milk and dairy products, cattle were brought to the republic from abroad. The Holstein breed possesses quite good adaptive properties, a high genetic index and adaptability to a modern milking installation. It should be noted that the use of the gene pool of the Holstein breed of red and variegated color in herds of red steppe cattle increases the milk yield of the crossbred offspring and improves the multifunctional properties of the udder. In Dagestan, the breeding of purebred cattle of the red steppe breed did not give such obvious positive results, and therefore, from the end of the last century, they began to be crossed with Angler and Holstein red - variegated breeds $[8,9,15]$.

The aim of the research was to study the development of heifers of the Red Steppe breed and its crosses with the Holstein breed during pregnancy and after calving in a particular farm. The advantage of the Holstein breed is its high milk yield and technological properties of the udder. Highly productive for the Holstein breed, hybrids are more abundant in milk and are well adapted for use in modern highly mechanized milk production complexes. This is the OJSC "Kizlyaragrokompleks" of the Kizlyar region, located in the lowland zone of the Republic of Dagestan. Studies show that under the same conditions of feeding and keeping first-calf heifers $1 / 2$ - blood in Holstein red motley compared to purebred steppe red and $3 / 4$ blood in improving breed differed in high indicators of milk productivity $[6,7,10,11]$.

\section{Material and methods}

Scientific and economic experience is held in open joint-stock company " Kizlyaragrokompleks " of Kizlyar district, Dagestan republic, on heifers and cows, heifers of Red Steppe breed and their hybrids of different blood Holstein.

The object of research was pure-bred animals of the red steppe breed and crossbreeds $1 / 2$ and $3 / 4$ of blood according to Holstein. According to the principle of pairs - analogues, taking into account the age, live weight, origin and milk productivity of mothers, 3 groups of heifers were formed at 6 to 7 months of pregnancy, 10 animals each. Group I included animals of the red steppe breed, in II $-1 / 2$ blood, in III $-3 / 4$ blood according to Holstein.

\section{Results}

The growth and development of animals was taken into account by weighing and taking the main measurements of the exterior at 6-7 months of pregnancy and at 2-3 months of lactation, and based on the obtained data, body indices were calculated.

The livestock is represented by the red steppe breed and its crossbreeds, of which $44.1 \%$ are purebred cows, $14.7 \%$ crossbreeds of the 4-th generation, $23.3 \%$ of the 3 rd generation, and $17.9 \%$ of the 2 nd and 1 st generation.

Animals of the red steppe breed of open joint-stock company (OJSC) "Kizlyaragrokompleks", as in other farms in the low zone of Dagestan, are physically specialized in the dairy. Owing to measures aimed at intensifying livestock, the milk productivity of cattle is increasing from year to year. Milk yields per feed cow increased from $3,500 \mathrm{~kg}$ in 2018 to 4,000 or more $\mathrm{kg}$ in 2019. 
The level of feeding and the intensity of growing heifers should be consistent with the expected milk production.

Heifers and cows should always have fresh, high-quality and attractive feed, both of their own production and purchased. The nutrition received by the first-calf is used to meet the needs of its own growth in energy and protein, partly to maintain life and form products. The general level of feeding of heifers to calving should be at least 9 EFU (energetic feed unit) per day, and the level of protein nutrition should be 100-106 g per 1 EFU of the diet. Irregular and inadequate feeding is often the cause of dysfunctional calving, receiving weak calves and low productivity of cows - first heifers.

Feeding and maintenance of experimental animals of three groups was organized according to the technology adopted in the farm - loose group and the level of feeding, providing 500-600 g increase in live weight per day. At the same time, attention is drawn to that circumstance. That under the same conditions of feeding and keeping, the ontogenesis of heifers of different groups, depending on the origin and breed, took place with different intensities. So, at 6-7 months of pregnancy, heifers of the second and third groups of 50 and $75 \%$ of blood in the Holstein breed had a live weight of $375.5-388.4 \mathrm{~kg}$, which is 8.4 $12.0 \%$ more than in the first.

Table 1. Diet for feeding heifers during stall and pasture periods.

\begin{tabular}{|l|c|c|}
\hline \multirow{2}{*}{ Indicator } & \multicolumn{2}{|c|}{ Periods } \\
\cline { 2 - 3 } & stall & pasture \\
\hline Bean hay - forb, kg & 7 & - \\
\hline Corn silage, kg & 4 & - \\
\hline Haylage, $\mathrm{kg}$ & 5 & - \\
\hline Herb forbs, kg & \multicolumn{2}{|c|}{ plenty } \\
\hline Compound feed, kg & 2.5 & 32 \\
\hline Salt - licks & \multicolumn{2}{|c|}{} \\
\hline The diet contains: & 9.2 & 9.4 \\
\hline EFU (energetic feed unit) & 92 & 94 \\
\hline exchange energy, MJ & 89.5 & 95 \\
\hline dry matter, kg & 1200 & 1187 \\
\hline crude protein, g & 966 & 990 \\
\hline digestible protein, g & 710 & 750 \\
\hline starch, g & 402 & 421 \\
\hline sugar, g & 287 & 300 \\
\hline crude fat, g & 1486 & 1537 \\
\hline crude fiber, g & 43 & 48.5 \\
\hline calcium, g & 21.2 & 27.4 \\
\hline phosphorus, g & 20.5 & 23.2 \\
\hline magnesium, g & 24.8 & 30.8 \\
\hline sodium, g & 145 & 159 \\
\hline potassium, g & 12.9 & 14.7 \\
\hline sulfur, g & 1190 & 1230 \\
\hline iron, mg & 70.1 & 69.8 \\
\hline copper, mg & 238 & 245 \\
\hline zinc, mg & 456 & 474 \\
\hline manganese, mg & 2.3 & 2.7 \\
\hline iodine, mg & 279 & 296 \\
\hline carotene, mg & - & 4.3 \\
\hline vitamin D, thousand IU & 873 & 901 \\
\hline vitamin E, mg & & \\
\hline
\end{tabular}

The rational feeding of heifers should be organized on the basis of the norms of animal nutritional requirements and in accordance with a growth plan that provides for the rearing 
of cows with a live weight gain of $500-550 \mathrm{~kg}$. These indicators can fluctuate in the direction of decrease depending on the breeding zone of animals of this breed. During the period of pregnancy and lactation, the animals were in the same feeding conditions and keeping. The consumption of feed units of cows amounted to $3760 \mathrm{~kg}$ and digestible protein per 1 feed unit $-113.8 \mathrm{~g}$.

Intensive growth of heifers can significantly reduce the time required for raising cows. Upon receipt of the average daily growth of heifers of 500-600 $\mathrm{g}$ for the entire growing period and their insemination at the age of 16-18 months. live weight of $360-400 \mathrm{~kg}$, the achievement of live weight of full-aged cows of more than $550 \mathrm{~kg}$ and not less than 4000 $\mathrm{kg}$ of milk per lactation is guaranteed .

The main indicators characterizing the growth and development of farm animals are live weight and growth rate. The growth of animals is taken into account by various methods, the most common method of accounting for changes in the size of the animal's body is systematic weighing. This method is the most accurate for determining the growth rate of an animal $[2-4,9]$.

Table 2. The dynamics of the live weight of animal bloodiness for Holstein.

\begin{tabular}{|c|c|c|c|}
\hline \multirow{2}{*}{ Age } & \multicolumn{3}{|c|}{ Group } \\
\cline { 2 - 4 } & I & II & III \\
\hline at 6-7 months of pregnancy & $370.6 \pm 1.60$ & $375.5 \pm 1,63$ & $388.4 \pm 1.72$ \\
\hline at 2 - 3 months of lactation & $399 \pm 1.76$ & $411 \pm 2.15$ & $409 \pm 1.38$ \\
\hline
\end{tabular}

From the data obtained, it can be seen that in terms of live weight, both heifers and firstcalf cows of different genotypes did not differ much between themselves.

Cows - first-calf heifers of the Red Steppe breed at 2 - 3 months of lactation weighed $399 \mathrm{~kg}$, which is $2.92 \%$ less than II ( $1 / 2$ blood count) and $2.45 \%$ III ( $3 / 4$ blood count).

In conditions of intensive technology, not only live weight of paramount is importance, but also the exterior-constitutional features of animals, which are characterized by measurements of the exterior and body indices [6,12].

Evaluation of animals by measurement has entered the zootechnical practice of measuring animals since the second half of the 19th century, when the system of projects for cattle, horses has been developed and special measuring devices (a measuring stick, a measuring compass) have been designed. At present, the measuring stick, the measuring compass and measuring tape - tape measure are used to assess the exterior of animals by measurements. The measurement of animals also provides the opportunity to obtain the degree and nature of the development of various parts of the animal's body in absolute values. The obtained absolute data allow to compare one animal with another, in addition, they provide the opportunity to trace the dynamics of the growth of individual parts of the animal's body in different segments - ontogenesis $[8,10]$.

The measuring method or the method of measurements for the assessment of the exterior of animals is more objective in relation to the characteristics of the development of individual parts of the external_appearance in absolute values, but at the same time this method does not give such an understandable idea of the animal as a whole, which is formed by its direct examination with a large assessment of it. The objectivity and accuracy of this method are somewhat relative, as all the measurements are associated with error estimation. The source of these errors can be errors of different nature. They are instruments, personal qualities of a specialist, nature of measurement, etc. Therefore, the statistical processing of measurement indices is used to get rid of various kinds of errors in zootechnical practice. The separate measurements, expressed in absolute values, by themselves, cannot characterize the peculiarity of the animal's exterior as a whole, as each measurement is considered separately and in isolation, without any connection with others. 
In this regard, in the practice of animal husbandry, for the more objective assessment of the animal physique, the methods of calculation and determination of indices are used [2,9].

Therefore, to obtain a clearer and more complete picture of the growth and development of animals, along with weighing, measurements of exterior articles are also carried out. Studying the growth and development of animals by measurement makes it possible to objectively characterize a specific animal or group of animals $[9,11]$.

To identify the exterior features of the studied animals, 10 main measurements were taken, the data of which are shown in table 3.

Table 3. The main measurements of the exterior of experimental animals, $\mathrm{cm}$.

\begin{tabular}{|c|c|c|c|c|c|c|}
\hline \multirow{4}{*}{ Index } & \multicolumn{6}{|c|}{ Group } \\
\hline & \multirow{2}{*}{\multicolumn{2}{|c|}{ I }} & \multicolumn{2}{|c|}{ II } & \multicolumn{2}{|c|}{ III } \\
\hline & & & \multicolumn{2}{|c|}{ Age } & \multicolumn{2}{|c|}{ Age } \\
\hline & $\begin{array}{c}6-7 \\
\text { months } \\
\text { pregnancy }\end{array}$ & $\begin{array}{c}2-3 \\
\text { months } \\
\text { lactation }\end{array}$ & $\begin{array}{c}6-7 \\
\text { months } \\
\text { pregnancy }\end{array}$ & $\begin{array}{c}2-3 \\
\text { months } \\
\text { lactation }\end{array}$ & $\begin{array}{c}6-7 \\
\text { months } \\
\text { pregnancy }\end{array}$ & $\begin{array}{c}2-3 \\
\text { months } \\
\text { lactation }\end{array}$ \\
\hline $\begin{array}{c}\text { Height in } \\
\text { withers }\end{array}$ & $\begin{array}{c}122.4 \pm \\
1.1\end{array}$ & $\begin{array}{c}126.0 \pm \\
2.2\end{array}$ & $\begin{array}{c}124.8 \pm \\
0.6\end{array}$ & $\begin{array}{c}126.5 \pm \\
0.5\end{array}$ & $\begin{array}{c}123.8 \pm \\
0.9\end{array}$ & $\begin{array}{c}126.0 \pm \\
0.8\end{array}$ \\
\hline Sacral height & $\begin{array}{c}127.5 \pm \\
1.6\end{array}$ & $\begin{array}{c}131.2 \pm \\
1.6\end{array}$ & $\begin{array}{c}130.1 \pm \\
0.6\end{array}$ & $\begin{array}{c}135.0 \pm \\
0.5\end{array}$ & $\begin{array}{c}128.8 \pm \\
0.4\end{array}$ & $\begin{array}{c}132.8 \pm \\
0.8\end{array}$ \\
\hline Chest width & $34.5 \pm 0.5$ & $\begin{array}{c}35.1 \pm \\
0.4\end{array}$ & $35.0 \pm 1.0$ & $\begin{array}{c}36.2 \pm \\
0.7\end{array}$ & $35.2 \pm 1.0$ & $\begin{array}{c}35.5 \pm \\
0.5\end{array}$ \\
\hline Chest depth & $65.1 \pm 0.8$ & $\begin{array}{c}67.0 \pm \\
1.7\end{array}$ & $66.2 \pm 0.8$ & $\begin{array}{c}69.0 \pm \\
0.8\end{array}$ & $65.5 \pm 0.5$ & $\begin{array}{c}67.8 \pm \\
0.6\end{array}$ \\
\hline $\begin{array}{c}\text { Chest } \\
\text { circumference }\end{array}$ & $174.2 \pm 2$ & $\begin{array}{c}177.1 \pm \\
0.9\end{array}$ & $\begin{array}{c}176.1 \pm \\
1.3\end{array}$ & $\begin{array}{c}179.0 \pm \\
0.6\end{array}$ & $\begin{array}{c}175.3 \pm \\
0.5\end{array}$ & $\begin{array}{c}178.0 \pm \\
0.6\end{array}$ \\
\hline $\begin{array}{l}\text { Scythe torso } \\
\text { length }\end{array}$ & $\begin{array}{c}153.0 \pm \\
1.1\end{array}$ & $\begin{array}{c}157.2 \pm \\
1.1\end{array}$ & $\begin{array}{c}157.1 \pm \\
0.8\end{array}$ & $\begin{array}{c}161.0 \pm \\
0.8\end{array}$ & $\begin{array}{c}155,2 \pm \\
0.4\end{array}$ & $\begin{array}{c}160.1 \pm \\
0.4\end{array}$ \\
\hline $\begin{array}{c}\text { Width } \\
\text { maklokah }\end{array}$ & $45.1 \pm 0.8$ & $\begin{array}{c}46.0 \pm \\
0.6\end{array}$ & $46.2 \pm 0.4$ & $\begin{array}{c}44.5 \pm \\
0.5\end{array}$ & $46.7 \pm 0.4$ & $\begin{array}{c}45.5 \pm \\
0.3\end{array}$ \\
\hline $\begin{array}{l}\text { Hip Width . } \\
\text { articulated. }\end{array}$ & $49.5 \pm 0.5$ & $\begin{array}{c}50.3 \pm \\
0.8 \\
\end{array}$ & $49.4 \pm 0.3$ & $\begin{array}{c}49.9 \pm \\
0.3 \\
\end{array}$ & $49.9 \pm 0.3$ & $\begin{array}{c}50.2 \pm \\
0.8 \\
\end{array}$ \\
\hline $\begin{array}{l}\text { Width at the } \\
\text { shoulder } \\
\text { joints }\end{array}$ & $42.3 \pm 0.8$ & $\begin{array}{l}44.2 \pm \\
0.5\end{array}$ & $44.1 \pm 0.6$ & $\begin{array}{c}46.3 \pm \\
0.5\end{array}$ & $43.5 \pm 0.4$ & $\begin{array}{c}45.5 \pm \\
0.5\end{array}$ \\
\hline $\begin{array}{c}\text { Metacarpal } \\
\text { circumference }\end{array}$ & $18.1 \pm 0.3$ & $\begin{array}{c}18.2 \pm \\
0.3\end{array}$ & $18.5 \pm 0.3$ & $\begin{array}{c}18.7 \pm \\
0.3\end{array}$ & $18.1 \pm 0.3$ & $\begin{array}{c}18.3 \pm \\
0.2\end{array}$ \\
\hline
\end{tabular}

The combination of exterior and interior evaluations is based on the boundary of the relationship between the unity and integrity of a living organism. The interior features of the body are associated with the growth and development of young animals, reproductive characteristics, and especially with the productivity of bred animals $[1,5,14,15]$

Measurements of the exterior of animals at $6-7$ months of pregnancy and $2-3$ months of lactation, shown in the table, show that there are not large differences in measurements of the exterior between animals of different genotypes, except for height at the withers, oblique length of the trunk and width in hook bone.

First-calves $1 / 2$ bloodiness at 2-3 months of lactation had the best measurements of the exterior and superiority over pure - bred animals was $0.5 \mathrm{~cm}$ or $2.5 \%$ in height at the withers, metacarpus girth $-0.5 \mathrm{~cm}$ or $2.8 \%$, girth breasts $-1 \mathrm{~cm}$ or $0.6 \%$.

Consequently, the analogues of group II were more wide-bodied, half-blooded animals were more tall and long-bodied, analogues of group III occupied an intermediate position.

A characteristic feature of the formation of the general physique of experimental animals is the unevenness of the intensity of growth of various articles of the exterior with age. 
Comparing the indicators of the exterior of all three groups, it can be noted that there were no significant differences in the indicators of the measurements taken into account by us, obviously, the exterior features of the animals were not associated with Holstein blood.

The evaluation of animals by the determination of indices is a follow-up of the measuring method of exterior parts. To calculate the indices, the absolute indicators, obtained by measuring various parts of the exterior are used and not any measurements, but those ratios of which most characterize the proportions of the animal's body as a whole. The reasonably calculated indices give the opportunity to judge of the degree and nature of organism development, the proportions of its physique and the general constitutional type. Therefore, to assess the proportions of the body, the harmony of its build and the relative development of individual parts of the body, physique indices are calculated, that is, the ratio of anatomically related measurements, but not any measurements, expressed as a percentage. The physique indices make it possible to judge objectively of the characteristics and differences in the animal build of different sex, age and breed. [5,12].

To fully characterize the physique of the experimental animals, the most important indices were calculated that characterize the constitutional features, the degree of growth and development of the animal, which are reflected in Table 4.

Table 4. The indices of heifer's physique at the age of $6-7$ months. pregnancy and 2-3 months.

Lactation.

\begin{tabular}{|c|c|c|c|c|}
\hline № & Index & Group & $\begin{array}{c}6-7 \text { months } \\
\text { pregnancy }\end{array}$ & $\begin{array}{c}2-3 \text { months } \\
\text { lactation }\end{array}$ \\
\hline \multirow{3}{*}{1.} & \multirow{3}{*}{ Leggy } & $\mathrm{I}$ & $46.8 \pm 0.7$ & $45.2 \pm 0.8$ \\
\hline & & II & $47.1 \pm 0.6$ & $47.0 \pm 0.7$ \\
\hline & & III & $47.0 \pm 0.7$ & $46.2 \pm 0.7$ \\
\hline \multirow{3}{*}{2.} & \multirow{3}{*}{ Stretch } & I & $125.0 \pm 1.0$ & $124.6 \pm 1.0$ \\
\hline & & II & $125.8 \pm 0.8$ & $127.3 \pm 0.7$ \\
\hline & & III & $125.2 \pm 1.2$ & $127 \pm 0.6$ \\
\hline \multirow{3}{*}{3.} & \multirow{3}{*}{$\begin{array}{l}\text { Pelvic thoracic } \\
\text { index }\end{array}$} & I & $74.8 \pm 2.1$ & $78.3 \pm 1.9$ \\
\hline & & II & $76.7 \pm 1.3$ & $78.6 \pm 0.9$ \\
\hline & & III & $75.0 \pm 1.7$ & $78.0 \pm 1.4$ \\
\hline \multirow{3}{*}{4.} & \multirow{3}{*}{ Breast } & I & $53.9 \pm 2.0$ & $52.2 \pm 0.8$ \\
\hline & & II & $54.3 \pm 1.0$ & $52.4 \pm 1.1$ \\
\hline & & III & $53.4 \pm 1.6$ & $52.8 \pm 1.2$ \\
\hline \multirow{3}{*}{5.} & \multirow{3}{*}{ Fortitude } & I & $110.8 \pm 2.0$ & $110.5 \pm 0.6$ \\
\hline & & II & $115.0 \pm 1.1$ & $112.7 \pm 0.3$ \\
\hline & & III & $112.9 \pm 0.5$ & $111.2 \pm 0.6$ \\
\hline \multirow{3}{*}{6.} & \multirow{3}{*}{ Boniness } & I & $14.6 \pm 0.4$ & $14.3 \pm 0.3$ \\
\hline & & II & $14.8 \pm 0.3$ & $14.6 \pm 0.2$ \\
\hline & & III & $14.7 \pm 0.4$ & $14.5 \pm 0.2$ \\
\hline \multirow{3}{*}{7.} & \multirow{3}{*}{ Average body width } & I & $42.5 \pm 0.7$ & $42.5 \pm 0.65$ \\
\hline & & II & $42.0 \pm 0.6$ & $42.9 \pm 0.57$ \\
\hline & & III & $42.4 \pm 0.7$ & $42.9 \pm 0.69$ \\
\hline \multirow{3}{*}{8.} & \multirow{3}{*}{ Average body height } & I & $124.9 \pm 1.1$ & $128.5 \pm 1.2$ \\
\hline & & II & $127.0 \pm 1.3$ & $131 \pm 1.19$ \\
\hline & & III & $126.3 \pm 1.1$ & $129.7 \pm 1.28$ \\
\hline \multirow{3}{*}{9.} & \multirow{3}{*}{ Specialization Index } & I & $33.2 \pm 0.4$ & $33.07 \pm 0.3$ \\
\hline & & II & $33.0 \pm 0.3$ & $32.7 \pm 0.2$ \\
\hline & & III & $33.1 \pm 0.4$ & $33.07 \pm 0.4$ \\
\hline
\end{tabular}

The data presented clearly show that cows with different bloods according to the 
Holstein breed had rather noticeable differences in the indicators of the following body build indices: leggy, elongation, chest. The value of the long-legged index in group II is $0.64 \%$ higher and $0.63 \%$ in group III as compared to group I, and elongation in group II is $6.36 \%$ higher than in group I. The breast index in half-bred animals is higher than in purebred animals by $0.4 \mathrm{~cm}(7.34 \%)$, and in $3 / 4$ bloodiness by $0.9 \mathrm{~cm}$ or $1.69 \%$.

With the aim of a deeper and more theoretical substantiation of the level of differences in biological processes occurring in the body of experimental animals of various origins, the biochemical parameters of blood were studied by the content of lipids, sugar and total protein.

Table 5. Biochemical parameters of the blood of experimental animals.

\begin{tabular}{|c|c|c|c|}
\hline \multirow{2}{*}{ Indicator } & \multicolumn{3}{|c|}{ Group } \\
\cline { 2 - 4 } & I & II & III \\
\hline Glucose, mmol / L & $3.3 \pm 0.081$ & $3.27 \pm 0.83$ & $3.245 \pm 082$ \\
\hline Total protein, g / L & $82.5 \pm 1.51$ & $83.2 \pm 1.56$ & $82.8 \pm 1.52$ \\
\hline Lipids, g / L & $3.9 \pm 0.017$ & $4.1 \pm 0.020$ & $4.0 \pm 0.019$ \\
\hline
\end{tabular}

It was found that with age of animals, lipids decrease, and the amount of sugars and total protein increases. At the same time, no significant differences between the groups depending on bloodiness in Holstein were found.

The origin of animals, their belonging to various genealogical groups, has a great influence on the milk productivity of cows and on its quantitative and qualitative indicators. Other things being equal, the level of milk production and milk composition of different cows is different. To determine the influence of blood in the Holstein breed on the indicators of milk productivity of cows of improved breeds, an analysis was made of changes in milk yield and fat content in milk in the same animals during the first months of lactation.

This is evidenced by the research data on the livestock of the red steppe breed and its crossbreeds (Table 6).

Table 6. Average milk yield of cows.

\begin{tabular}{|c|c|c|c|}
\hline Group & $\begin{array}{c}\text { Number } \\
\text { of heads }\end{array}$ & $\begin{array}{c}\text { Milk yield per lactation } \\
\text { on average, } \mathrm{kg}\end{array}$ & $\begin{array}{c}\text { Average fat } \\
\text { content in milk, } \%\end{array}$ \\
\hline I & 10 & $3450 \pm 55.1$ & $3.75 \pm 0.02$ \\
\hline II & 10 & $3750 \pm 57.8$ & $3.90 \pm 0.02$ \\
\hline III & 10 & $3600 \pm 77.1$ & $3.85 \pm 0.02$ \\
\hline
\end{tabular}

From the data obtained, it follows that the best indicators in terms of milk yield have cows belonging to group II, they exceeded their peers from group I by $300 \mathrm{~kg}$ or $8.0 \%$, and group III by $150 \mathrm{~kg}$ or $4.2 \%$. The difference between groups II and III is close to reliability, and the difference between groups II - I is reliable.

What matters is such an indicator of productivity as the fat content in milk. The research results show that the highest fat content in milk belongs to the cows of the II group $-3.90 \%$, in the second place is their contemporaries of the III groups $-3.85 \%$ and the I group is closed by the cows of the red steppe breed. Cows of group II outnumbered their peers from groups I and III by 0.15 and $0.5 \%$, respectively. The difference in fat content in milk was not significant.

The economic efficiency of milk production is noted by many factors and the final indicator on which the further use of animals for the reproduction and production of large quantities of milk depends is the breeding of a certain animal genotype [13,15]. 
Table 7. Cost-effective milk production of experimental cows for the first lactation.

\begin{tabular}{|l|c|c|c|}
\hline \multirow{2}{*}{ Index } & \multicolumn{3}{|c|}{ Group } \\
\cline { 2 - 4 } & I & II & III \\
\hline Milk yield of natural milk, kg & 3450 & 3750 & 3600 \\
\hline The fat content of milk,\% & 3.75 & 3.90 & 3.85 \\
\hline $\begin{array}{l}\text { Milk yield of basic (3.4\%) fat } \\
\text { content, kg }\end{array}$ & 3805.15 & 4301.47 & 4076.47 \\
\hline Live weight of cows, kg & 423 & 444 & 436 \\
\hline $\begin{array}{l}\text { Milk yield per 100 kg of live } \\
\text { weight }\end{array}$ & 815.6 & 844.6 & 825.7 \\
\hline Production Costs pro head, rub. & 48000 & 48000 & 48000 \\
\hline Selling price 1 kg / rub. & 23.0 & 23.0 & 23.0 \\
\hline $\begin{array}{l}\text { Proceeds from the sale of milk at } \\
\text { a cost of 23 } \\
\text { rubles/ kg . }\end{array}$ & 87518.45 & 98933.81 & 93758.81 \\
\hline Profit from the sale of milk, RUB & 39518.45 & 50933.81 & 45758.80 \\
\hline Profitability level,\% & 45.6 & 51.49 & 48.81 \\
\hline
\end{tabular}

A comparative analysis of the economic efficiency of milk production showed that with the same sales value of products, the cost of milk production and profit from its sale were different.

Different levels of productivity have been obtained from cows of different genealogical groups, which have not the same cost of production. According to sales prices (23.0 rubles / $\mathrm{kg}$ ), the cost of dairy products obtained from cows of the II group amounted to $98,933.81$ rubles, which is $11.54 \%$ more compared to I and $5.52 \%$ more than in III. The consumption of feed units to obtain $\mathrm{kg}$ of milk in the first group was 1.77 , against 1.54 in the second and 1.71 in the third. Hence it follows that the highest payment for fodder with products is noted for cows of the II group, that is, the highest productivity, and, conversely, the lowest level of payment for fodder with products in the I group, where is the lowest productivity. All this testifies to the fact that cows of the II group are the best in the conditions of this farm. Consequently, payment for fodder with products is in direct proportion to the level of productivity of animals. This indicates that in a herd of cows there are various genealogical groups of animals capable of not only high productivity, but also better payment for forage products.

\section{Discussion}

The correct and rational organization of the cultivation of remount heifers of dairy and milk - meat breeds increases early maturity, promotes the formation of large, highly productive cows and shortens the period of their cultivation. The level of intensity of heifers should be determined taking into account the breed of cattle, the level of herd productivity, the age of heifers to the first calving and the type of animal feeding. Comparing body indices by groups, it can be noted that, according to these indicators, no significant differences are found between heifers of both groups. But at the same time, it should be noted that the specialization index in all three groups showed belonging to the dairy type - 33.2, 33.0 and 33.1 .

\section{Conclusion}

Thus, breeding of semi-blooded animals of Holstein breed in the lowland zone of Dagestan is economically viable, since at higher milk production they better pay for feed 
and thereby contribute to cheaper products and increase the profitability of the industry. There were no significant differences between the groups in terms of exterior features and blood biochemical composition. An analysis of the data shows that the crossing of cows of the red steppe breed with bulls of Holstein red-motley contributes to an increase in the economic efficiency of milk production.

\section{References}

1. O. V. Ageeva The effect of holsteinization on the milk productivity of cows, Actual problems of the intensive development of animal husbandry: materials of the XIII international scientific and practical conference, 367 -369 (2010)

2. P. A. Aligazieva The development and reproductive performance of young red steppe breed, grown under different conditions of feeding The development problems of the Agro-Industrial Complex in the region 4 (16), 41-45. (2013)

3. Aligazieva The influence of different periods of calving on the efficiency of milk production, The development problems of the Agro-Industrial Complex in the region, 1 (37), 166-170 (2019)

4. E. Belenkaya The age influence of first calving on the productivity of Holstein cows, Collection of articles of the All-Russian scientific conference "Integration of science and practice for the development of the agricultural sector", 16-22 (2017)

5. D. G. Zalibekov Reproductive qualities of the red steppe breed and its crosses with Holstein The development problems of the Agro-Industrial Complex in the region, 1 (29), 77-80 (2017)

6. Zelenkov The desired type of Holstein cows and prognosis of selection efficiency, $\mathbf{1}$, 201-205 (2007)

1. A. Zelenkova The selection and genetic parameters of the main indicators of the Holstein cow's productivity, 1, 206-208 (2007)

7. Kh.M. Kebedov, A. Aligazieva, M. B. Ulimbashev, A. Kebedova Productive features of red steppe and holstein cattle of different types of constitution, The development problems of the Agro-Industrial Complex in the region, 3 (39), 172-177 (2019)

8. Kh.M. Kebedov, D.G Zalibekov, A. Kebedova The development problems of the Agro-Industrial Complex in the region, 1 (17), 40-43 (2014)

9. S.V. Rotov, N.A. Skorkina The effectiveness of the influence of various lines of bulls on the milk productivity of cows ,7, 2-3 (2012)

10. M.M. Sadykov, R.M. Chavtaraev, M. Alikhanov, O.A. Gasanguseynov, Kh.M. Kebedov The development problems of the Agro-Industrial Complex in the region, 3 (35), 109-111 (2018)

11. M.M. Sadykov, R.M. Chavtaraev, A.O. Alikhanov Some productive and physiological indicators of red steppe and crossbred heifers, International Research Institute of Livestock, 3 (34), Part 2, 35-37 (2015)

12. N.I. Strekozov, V.I. Chinarov Milk production in the regions of the Russian Federation until 2020 should be predictable Dairy and beef cattle breeding, 4, 2-4 (2014)

13. N.I. Tatarkina, M.A. Svyazhenina, N.A. Loseva Using the productive potential of the Holstein breed Agrarian Bulletin of the Urals, 5 (97), 58-60 (2012)

14. M.B. Ulimbashev, A.F. Shevkhuzhev, G.N. Chokhataridi Perfection of red steppe cattle in the North Caucasus, 4, 11-13 (2012) 